\title{
Categorization, Characterisation, Management and Future Trends of Solid Wastes in Ado-Ekiti, Nigeria
}

\author{
Ibimilua Adewale Festus \\ Department of Geography and Planning Science, Faculty of the Social Sciences, Ekiti State University, Ado-Ekiti, Ekiti State Nigeria \\ Email: wibimilua@yahoo.com

\section{Ibimilua Foyeke Omoboye} \\ Department of Geography, School of Arts and Social Sciences, College of Education, Ikere-Ekiti, Ekiti State Nigeria \\ Email: fibimilua@yahoo.com
}

\section{Doi:10.5901/mjss.2015.v6n4s3p628}

\section{Abstract}

\begin{abstract}
This research work aims at investigating the categories, characteristics and management of solid wastes in Ado-Ekiti Nigeria. Data for the study were collected from both primary and secondary sources. The methodology for primary data collection includes preliminary study, observation, focus group discussion, and interviews, as well as administration of questionnaire. 468 copies of the questionnaire were administered on randomly selected respondents from 3 different residential zones of the city (low, medium and high). Secondary data were collected mainly from Ekiti State Waste Management Board as well as Ekiti State Ministry of Environment. The data were analysed using simple tools of analysis like tables, frequencies and percentages. Findings from the study revealed that 80 tons of wastes are generated and disposed off in Ado-Ekiti on daily basis. The most prominent categories of the waste are agricultural, municipal and domestic. The major constraints to efficient waste management are technical, financial, institutional, economic and social deterrents. The prominent media of waste collection in the study area are drums and dust bins. Likewise, the storage facilities are dinno bins and wheelie bins. The wastes are transported to the dumping ground irregularly. The study revealed further that wastes are not properly managed in Ado-Ekiti. The menace has posed social, economic and environmental consequences. The major hindrances to efficient waste management are technical, financial, institutional, economic and social limitations. Hence, the study recommends that there should be a collaborative effort among individuals, government and non-governmental organizations in the management of solid wastes. The study concludes that reduction, reuse, and recycling are the best practices for sustainable solid waste management.
\end{abstract}

Keywords: Environment, Health, Pollution, Sanitation, Recycling.

\section{Introduction}

Ever since he appeared on the face of the Earth, man has exploited and modified the environment to his advantage in many ways (Rao, 2006). Several problems emanate from the process of transformation of the environment. Also, many waste products are generated from how man lives and how he makes his living in the environment. People produce an enormous amount of waste which has to be disposed off. Past disposal or accidental release, of toxic waste has left a heritage of contaminated land which needs to be cleared up (NERC, 2006).

Solid waste has many definitions and various ways of classification (Ajadike, 2007). In its most elemental form, it can be defined as any discarded, useless, or unwanted material that is not in the gaseous or liquid form. It includes all those solid and semisolid materials that are discarded by a community (Garg and Garg, 2013). Something can become waste when it is no longer useful to the owner or it is used and fails to fulfill its purpose (Gourlay, 1992). In essence, wastes are generated from human interaction with the environment. They are materials or substances that are either spoiled, rejected or no longer required for their original purposes. Waste means any surplus or unwanted material or energy that is worn out, broken or contaminated. Environmental Protection Agency (1973) defined solid waste as useless, unwanted or discarded material with insufficient liquid content to be free flowing. This definition has been modernized because of the utility values that are embedded in solid wastes and the possibility of reuse and or recycling.

There has been a marked growth of interest in the quality of the urban environment both in the developed and developing world due to high concentration of people in towns and cities (Ojeifo and Uwadiae, 2003). Solid wastes and associated problems are confronting many urban and rural areas of the world (see Abrokwah, 1988; Adedibu, 1986; 
Gourlay, 1992; Zhiyong et al, 2015; Stirrup, 1965; Osinowo, 2001; Adedibu, 1986; Musa, 2006; Malombe 1993, Omuta, 1988; Arkerman, 1986; Kadafa, et al, 2013; and Garg and Garg, 2013). Urbanization, rapid modernization, economics growth and social breakdown are the major causes of the ever-increasing types and volume of solid wastes across the globe. In Nigeria, the menace of solid waste is causing more concern mainly because of the technical, financial, institutional, economic and social constraints that are associated with its management. The Nigerian environment and the intensive degradation and pollution it has been subjected to, by human activities and negligence, demand urgent and effective management (Franca, 2002).

\section{Literature Review}

Wastes emanate from agricultural, industrial, residential, institutional, municipal, commercial, mining, recreational and other human activities. Nigerian cities generate solid waste at an alarming rate that, in most cases, the volume of waste generated is often more than what the city system could absorb (Ademiluyi and Solanke, 2004). The problem is being compounded by poor transportation system, lack of storage facilities, and poor attitude of people towards waste management. The effects of the indiscriminate disposal and ineffective management of wastes include the social, economic, health and environmental consequences. The management of wastes involves the control of waste generation, packaging, collection, transportation, as well as the hygienic disposal. However, researches have confirmed that the most cost effective and efficient way to manage waste is to reduce waste (see Ajadike, 2008; Ademiluyi and Solanke, 2004; Iftekhar, 2004; Ojeifo and Uwadiae, 2003; Esieghe et al; 2007; Kayode and Omole, 2011; Fakere et al 2012; and Environmental Protection Agency, 1973).

Mangizvo (2010) examined the management practices at solid waste disposal sites in African cities and towns. He revealed that the general practice at the municipal dumpsites is not effective. He identified the threats posed by indiscriminate disposal of wastes as health hazards, environmental degradation, soil contamination, environmental pollution, as well as high rate of occupational health and safety hazards for the waste managers. Consequently, he suggested the perimeter fencing of dumpsites, integrated waste management, awareness and attitudes, education campaign, resources recovery and recycling activities, as well as the regulation of dumping system.

Solid wastes unlike other forms of waste (liquid and gaseous) are very difficult in handling because they occupy a lot of spaces. Some of the recent studies in waste management include Kadafa et al (2013) which examined the status of municipal solid waste management practices in Abuja, Nigeria. They found out that solid waste management represents one of the most crucial health and environmental problems facing many countries in Africa. Consequently, for the attainment of sustainable waste management, they suggested proper funding. Construction of access roads to landfills as well as provision of waste treatment plants.

Ojeifo and Uwadiae (2003) probed the waste disposal problems in Ekpoma and Irrua in Edo State, Nigeria. They noted that the occurrence of refuse dumps in our towns and cities has become a major concern to environmental health officers and managers. They opined that most urban centres have been characterized by a multiplicity of refuse heaps and a general deterioration in the sanitary quality of the environment. They identified the implications as reduction in the aesthetic quality of the environment, blockage of drainage channels and the consequent flooding implication, as well as threat to public health. Accordingly, they recommended environmental education, provision of waste disposal equipment, as well as the formulation and implementation of environmental protection laws.

The Management of waste is an integral part of ensuring a sound and safe environment. Fakere and Fadairo (2012) lamented on the increase in the volume of waste generated in Nigeria as well as the difficulties in the management of the waste. In their study on domestic waste management and urban residential environment in Akure, Nigeria, they found out that the phenomenal increase in the range and volume of waste generated is a direct consequence of rapid growth and urbanization. They identified the major problem in waste management as the arbitrary disposal of wastes. They submitted that the management of waste in any city is of paramount importance due to the risk posed to humans and the environment. They diagnosed the impacts of indiscriminate disposal of solid waste and reduction in air quality, global warming, soil degradation, contamination of ground water, flooding, as well as outbreak of diseases. As a result, they recommended public enlightenment, promulgation and enforcement of environmental laws, adequate funding, as well as provision of amenities.

The management of waste is a very important part of building a virile nation and sustainable environment. Serious environmental problems result (directly or indirectly) from poor management of solid waste. The management of waste requires the understanding of the categories, and characteristics for the best practice method of its disposal. Moreover, proper and efficient disposal of waste depends largely upon how and where solid waste is finally disposed. Above all, proper waste management is costly in terms of time and resources. The disposal of waste in safe, effective and 
sustainable manner requires collaborative efforts of individuals, parastatals, government and non-governmental organizations. Above all, the success of waste management is determined by good governance, prompt decision making as well as expeditious implementation of policies.

\section{Statement of the Problem}

Waste is an inevitable by-product of socio-economic and institutional activities. The problem of solid waste has been a major concern globally because of its numerous negative consequences on man and his environment. Similarly the strategies for the management of waste vary in terms of sector, region, time, contents of the potential waste materials, as well as the available resources for the superintendence of the waste. In Ado-Ekiti, Nigerian, waste management has continued to be a great concern over the year. Like other cities in developing countries of the world, the city town is having a serious problem of waste management ranging from generation, storage, collection, transportation, treatment to final disposal. The major problems of waste are indiscriminate dumping, poor means of storage, inefficient transportation and insanitary disposal.

The attitudes of people towards waste management are questionable. Many households dispose off their waste products in thorough drainage channels and rivers without any concern for environmental quality. This habit has several deleterious effects on man and his environment. These incudes health hazard, ground water contamination, pollution of agricultural (irrigation) water, reduction in food quality and quantity, as well as biodiversity loss. Moreover, the indiscriminate dumping of waste has led to the blockage of drainages, gutters and other passages. Also, the habit has created more breeding spaces for insects, pests, rodents and vectors of diseases like dysentery diarrhea and typhoid.

Most of the houses in the core areas of the city are not equipped with toilets and waste collection facilities, hence, the residents dispose off their solid wastes and even faeces into drainage channels. This is caused mainly by lack of environmental education and sanitation ethics.

Another major problem with the management of solid waste in Ado-Ekiti is lack of suitable site for the location of waste dumping sites. They are located haphazardly without due consideration to other land uses. In some neighbourhoods, waste products are dumped on the street without socio-economic and environmental considerations.

Unsanitary conditions are created as a result of illegal dumping of solid wastes on vacant plots, open spaces, abandoned buildings and other unauthorized sites in the neighbourhoods. The illegal dumping of refuse in gutters, drains, and waterways have led to serious problem of flooding at Adebayo, Ajilosun and Atikankan areas of Ado-Ekiti. Where wastes are dumped on the legally created dumping sites, the heaps of the garbage undergo putrefaction, thereby giving rise to offensive odours and the consequent health hazards. Whereas, wastes should be effectively disposed off and treated in such a way that they do not constitute nuisance or danger to public health or the environmental quality. Hence, the existing problem of waste management in Ado-Ekiti, the repercussions as well as the need for the sustainable management of wastes have prompted this research work.

\section{Objectives of the Study}

The objectives of the study are to:

(i) identify the categories of solid wastes.

(ii) account for the characteristics of solid wastes.

(iii) examine the methods of solid waste management.

(iv) find out the effects of indiscriminate solid waste disposal.

(v) investigate the problems that are hindering the sustainable management of solid wastes.

\section{Methodology}

The data for this study were collected from both primary and secondary sources. The method of data collection for the study includes reconnaissance survey, focus group discussion, personal observation, oral interviews, as well as questionnaire administration. A review of existing literature was done in order to gain an understanding of concepts, frameworks, components, emerging trends important considerations and strategies that are current in the field of solid waste management. A questionnaire was designed for the research. The questionnaire highlights the categories, characteristic, effects, administration and constraints to sustainable waste management. The questionnaire contained both open-ended and close-ended questions. Eighteen (18) final year students of Environmental Management at Ekiti State University, Ado-Ekiti, Nigeria were trained and used as research assistants. Four hundred and sixty eight (468) copies of the questionnaire were administered. One hundred and eighty seven 187 males and two hundred and eighty 
one (281) female respondents were randomly selected and interviewed. The reason for the bias is that females are more involved in the generation and management of waste in the study area than males. 407 copies of the questionnaire were correctly filled in and used for the purpose of the research. Moreover, the authorities of Ekiti State Waste Management Board, as well as those in the Ministry of Environment were interviewed. Simple descriptive, analytical and statistical tools like tables, percentages and frequencies were adopted in the data analysis.

\section{Categorization and Characterization of Waste}

Several human activities and land uses like urbanization, agriculture, commercial, transportation, residential and recreational endeavours have generated heaps of solid waste with its consequent degradation of the environment. The composition of the solid wastes varies from country to country and from season to season. Major classifications of solid wastes are garbage, rubbish, ashes, street sweeping, bulky wastes, municipal wastes, industrial wastes, hospital wastes, agricultural wastes, as well as demolition/construction wastes. Solid wastes are characterized by a great mixture of substances including plastic, metal, glass, textile and paper. Other components of solid wastes are ash, sewage sludge, household rubbish, waste from manufacturing activities, garden wastes, as well as packaging items.

Major characteristics of waste in the rural areas are agricultural materials, ashes, and dead animals, while the crucial components of waste products in urban centres are garbage rubbish, and industrial solid wastes. Other forms of waste are mining and minerals remains, sewage treatment solid, as well as large wastes. Exemplification of solid waste include broken bricks, broken glass and bottles, cans, plastics, paper, battery casing, plantain strings and nylon (Nigerian Institute of Safety Professionals, 2003). Wastes are unwanted or discarded materials at a particular place and time arising from normal community activities. They can be categorized under various headings. Among them are liquid, gaseous, solid, municipal, infections, and non-infectious. Specifically, solid waste may be categorized according to its origin as agricultural, industrial, domestic, recreational, institutional, commercial, construction, etc. It may also be grouped under the contents of plastic, rubber, paper, wood, glass, metal and organic materials. Solid wastes can also be classified according to their hazard potentials as infectious, flammable, radioactive, toxic, as well as non-toxic. Waste materials are also designated into categories like recydables, garbage or organic. Other forms of waste are construction and demolition, hazardous, non-hazardous, universal, radioactive as well as waste products from electrical and electronic equipment. Waste products could also occur in bio-medical, slaughter house, street offscourings or bulky forms.

\section{Effects of Solid Waste}

There are several effects of solid waste on man and his environment. Solid wastes and the inherent challenges are responsible for the degradation of water, land and air. It has contributed significantly to the destruction of the aesthetics of landscapes. Musa (2006) pointed out that effective solid waste management has been a major concern in most urban areas all over the world. In his examination of the nature, types and management of solid waste in Ankpa, Nigeria, he presented the problems that are associated with the generation, collection and disposal of wastes. He enumerated the impact of solid waste in form of pollution, changing landscape, traffic impediment, as well as aesthetic disfiguration of the environment. Other effects of solid waste are pollution of land and the nearby water bodies, transmission of diseases like cholera, dysentery, typhoid and gastro-enteritis, spread of food borne diseases, as well as environmental problems like flooding and traffic congestion on the street and road.

Solid wastes have the potential to cause significant damage to man and his environment. Some of the consequences on man's health are infections, spread of communicable diseases, as well as irritation. Other dangers equally emanate from waste to the environment. These include environmental pollution, destruction of ozone layer, acid rain, as well global warming. Furthermore, indiscriminate dumping of waste on the land affect agriculture in forms of diminution in soil fertility, reduction in cultivable land, as well as destruction of aquatic lives. Akinro et al (2014) examined the environmental impact of polyethylene generation and disposal in Akure, Nigeria. Findings from their study revealed that cellophane waste poses various threats to public health and adversely affect the flora and fauna components of the environment. In all, solid wastes affect man's health, the environment, agriculture and many other sectors of the economy. Poor waste management can hinder economic and invariably sustainable development.

\section{Management of Solid Wastes}

Waste management describes the diverse activities from generation, characterization, quantification, storage, handling collection, transportation, disposal and treatment of waste materials. It refers to the process of treatment and disposal of 
refuse, sewage and other wastes arising from human activities without creating public health nuisance in the community. Wastes are managed under some basic planning concepts like polluter pays, precautionary, proximity, duty of care, as well as waste hierarchy principles. Sustainable waste management falls under the broad headings of generation, storage, transportation, disposal and treatment. Appropriate manipulation of solid waste is a pre-requisite to the well-being and health of rural and urban dwellers. Researches have confirmed that effective management of solid waste eliminates or reduces detrimental effects on humans and the environment (see Musa, 2006; Omuta, 1988; Osinowo, 2001; and Zhiyong, 2015). Also, it enhances the quality of life and promotes socio-economic development.

Generally, common methods of solid waste disposal include incineration, sanitary landfill, recycling, ocean dumping and deep well injection. Other methods are burying, burning, open dumps, controlled tipping, livestock feeding, as well as decomposition of biodegradable solid wastes. Osinowo (2001) identified the common methods of solid waste disposal in Nigeria as open dumping, sanitary landfill, incineration, as well as composting. Integrated options of solid waste disposal for modern society includes reduction, recycling, reuse, recovery, renovation and regulation. The selection of a disposal method and site requires land, equipment, component of refuse, adequate fund, as well as skilled manpower. Stirrup (1965) opined that the method of refuse disposal must conform with the norms and values of the community, the climatic condition, the financial capacity of the community, as well as the type of waste being generated.

Kayode and Omole (2011) found out that the compositions of waste as well as the choice of method of solid waste disposal in Ibadan, Nigeria were reflections of variation of socio-economic factors of the people.

Malombe (1993) noted that waste management services are usually inadequate due to low priority given to waste management as well as weak capacity to handle it. Hence, he submitted that producers of wastes usually resolve into illegal dumping, open space dumping and indiscriminate burning. In his own case study of Duaka, Bangladesh, Iftekhar (2004) found out that over 3,000 tons of household wastes are produced daily and that less than half of it are collected while the remaining ones are left on roadsides, in open drains and low-lying areas. Therefore, he suggested the concept of 4 Rs' - reduce, reuse, recycle and recover as sustainable options for the management of solid waste. A similar study in Kumasi, Ghana by Abrowah, 1988 revealed that negligence, ignorance and lack of law to punish delinquents are the major problems of waste management in the city. To this end, he suggested environmental education, appropriate technology, as well as law enforcement for sustainable management of waste. In all, the determinants of solid waste management incudes economic, social, political and environmental considerations. The timely and cost-effective management of waste requires public awareness, provision of adequate infrastructure, adoption and development of technological process, enforcement of law and order, local research and development, as well as strategic planning.

\section{Findings and Discussions}

Scholars have pointed out that the problem of solid waste is not only peculiar to developing countries alone but cuts across the North and South worlds where the pollutant effects have caused considerable concern to individuals, government and environmentalists (see Fakere et al. 2012; Akinbode, 2012; Adedibu, 1986; Kharbanda and Stallworthy, 1992; Oluwande 1983; Ayeni, 1978; Abrokwah, 1988; Malombe, 1993; and Ackerman, 1996). The management of waste vary from place to place according to the component of waste, the available personnel, as well as technology. Solid waste management has remained one of the major problems in Ado-Ekiti, Nigeria. Findings from this study revealed that wastes are characterized by weight, volume, density and physical components.

Results from this study show that 80 tons of solid wastes are generated and disposed daily in Ado-Ekiti. The major sources of the waste materials are domestic activities (31.5\%), agriculture (18.9\%) commerce (10.3\%), institutions (10.1\%), vocational jobs (9.1\%), industries (7.6\%), services (6.6\%), as well as passer bys and vendors (5.9\%) (see table 1 ).

Table 1: Sources of Solid Wastes in Ado-Ekiti.

\begin{tabular}{|l|c|c|}
\hline Sources & Frequency & Percentage \\
\hline Domestic activities & 128 & 31.5 \\
\hline Agriculture & 77 & 18.9 \\
\hline Commerce & 42 & 10.3 \\
\hline Institution & 41 & 10.1 \\
\hline Vocational jobs & 37 & 9.1 \\
\hline Industries & 31 & 7.6 \\
\hline Services & 27 & 6.6 \\
\hline Passer bys and Vendors & 24 & 5.9 \\
\hline Total & 407 & 100 \\
\hline
\end{tabular}

Source: Field Survey, 2014 
The major constituents of waste products in Ado-Ekiti are food remnants (14.5\%), plastic, rubber, nylon and polythenes (14.0) ash and dust (12.3\%), papers and cartons (12.0\%), as well as leather and skin (10.3\%). Other are tin and metal (8.9\%), broken bottles and glass (8.1\%), wooden materials (7.1\%), rags and textiles (6.6\%), as well as aluminum and other materials (6.2\%) (see table 2).

Table 2: Constituents of Solid Wastes in Ado-Ekiti

\begin{tabular}{|l|c|c|}
\hline Constituent of Solid Waste & Frequency & Percentage \\
\hline Food ruminants & 59 & 14.5 \\
\hline Plastic, rubber, nylon and polythenes & 57 & 14.0 \\
\hline Ash and dust & 50 & 12.3 \\
\hline Papers and cartons & 49 & 12.0 \\
\hline Leather and skin & 42 & 10.3 \\
\hline Tin and metal & 36 & 8.9 \\
\hline Broken bottles and glass & 33 & 8.1 \\
\hline Wooden materials & 29 & 7.1 \\
\hline Rags and textiles & 27 & 6.6 \\
\hline Aluminum and other materials & 25 & 6.2 \\
\hline
\end{tabular}

Source: Field Survey, 2014

The commonly used media of refuse collection by the households are drums and dustbins (35.1\%), baskets and other containers (29.0\%) large polythene bags (24.8\%), beside the compound (6.7\%), as well as inside the drainage channels and gullies (1.7\%) (see tale 3).

Table 3: Medium of solid waste collection by the households

\begin{tabular}{|l|c|c|}
\hline Medium & Frequency & Percentage \\
\hline Drums and dust bins & 143 & 35.1 \\
\hline Baskets and other contained & 118 & 29.0 \\
\hline Large Polythene bags & 101 & 24.8 \\
\hline Beside the compound & 27 & 6.7 \\
\hline Inside the drainage & 11 & 2.7 \\
\hline Channels and gullies & 07 & 1.7 \\
\hline Total & 407 & 100 \\
\hline
\end{tabular}

Source: Field Survey, 2014

The wastes are stored at homes, places of work, industries and other public places for final collection and disposal. They are stored inside dustbins, dinno bins, and wheelie bins before they are collected and transported to the final disposal sites. Accessibility to dumping sites is a determinant of effective waste disposal. Findings from this study revealed that some households travel a very long distance before they can dispose off their solid wastes. For instance, people travel below 300 meters (13.5 \%), 201-400 metres (22.6\%), 401-600 metres (23.4\%), 601-800 metres (24.3\%), and above 800 metres (16.2\%) in order to dispose off their solid wastes (see table 4). The study revealed that the farther away the collection point or the final disposal site, the more the tendency to dispose off solid waste indiscriminately.

Table 4: Distance of dumping ground from household

\begin{tabular}{|l|c|c|}
\hline Distance (Metres) & Frequency & Percentage \\
\hline Below 200 & 55 & 13.5 \\
\hline $201-400$ & 92 & 22.6 \\
\hline $401-600$ & 95 & 23.4 \\
\hline $601-800$ & 99 & 24.3 \\
\hline Above 800 & 66 & 16.2 \\
\hline Total & 407 & 100 \\
\hline
\end{tabular}

Source: Field Survey, 2014 
The frequency of solid waste collection is one of the determinants of environmental sanitation. Results from this study show that wastes are collected at different intervals in the various locations. They are collected daily (31.0\%), thrice in week (31.9\%), twice in a week (30.7\%), or once in a week (6.4\%) as the case may be (see table 5).

Table 5: Frequency of solid waste collection

\begin{tabular}{|l|c|c|}
\hline Frequency of Collection & Frequency & Percentage \\
\hline Daily & 126 & 31.0 \\
\hline Thrice in a week & 130 & 31.9 \\
\hline Twice in a week & 125 & 30.7 \\
\hline Weekly & 26 & 6.4 \\
\hline Total & 407 & 100 \\
\hline
\end{tabular}

Source: Field Survey, 2014

Solid wastes are transported to the final disposal sites in Ado-Ekiti with the aid of tippers, tractors and dinno trucks. The wastes are handled carefully by the trained workers who are equipped with personal protective equipments like hand gloves, helmets, boots, nose masks, as well as aprons.

Sustainable disposal of solid waste depends on the methods that are available as well as the accessibility of such techniques. However, the frequently used methods in the study area are Ekiti State Waste Management Board (ESWMB) containers (32.9\%) collection by vendors (23.8\%), burning (14.0\%), burying (8.6\%), dumping ground (5.9\%), composting (5.4\%), on-street dumping (4.2\%), sanitary landfill (3.0\%) as well as animal feeding (2.2\%) (see table 6).

Table 6: Methods of Waste disposal

\begin{tabular}{|l|c|c|}
\hline Waste Disposal Methods & Frequency & Percentage \\
\hline Composting & 22 & 5.4 \\
\hline Dumping ground & 24 & 5.9 \\
\hline ESWMB container & 134 & 32.9 \\
\hline Collection by Vendors & 97 & 23.8 \\
\hline Burring & 57 & 14.0 \\
\hline Burying & 35 & 8.6 \\
\hline On-street dumping & 17 & 4.2 \\
\hline Sanitary landfill & 12 & 3.0 \\
\hline Animal feeding & 9 & 2.2 \\
\hline Total & 407 & 100 \\
\hline
\end{tabular}

Source: Field Survey, 2014

The wastes are finally, disposed off at open dumping sites by tractors, tippers and dinno trucks. The treatment of the waste entails the sorting, fumigation and recycling as the case may be. The sorting and recycling of the waste materials take place at the recycling plant along llokun village in Ado-Ekiti. Findings from the study revealed that some of the challenges that are associated with the sites where solid wastes are dumped in Ado-Ekiti are public health risk (41.0\%), aesthetic pollution of the environment (18.9\%), unpleasant odour from wastes (15.3\%), and littering of the environment (13.3\%). Others are disturbance of traffic flow (7.6\%), as well as ground water contamination (3.9\%) (see table 7).

Table 7: Problems relating to sites where solid, wastes are dumped in Ado-Ekiti

\begin{tabular}{|l|c|c|}
\hline Problem of Dumping Sites & Frequency & Percentage \\
\hline Public health risk & 167 & 41.0 \\
\hline Aesthetic pollution of the environment & 77 & 18.9 \\
\hline Unpleasant odour from wastes & 62 & 15.3 \\
\hline Littering of the environment & 54 & 13.3 \\
\hline Disturbance of traffic flow & 31 & 7.6 \\
\hline Ground water contamination & 16 & 3.9 \\
\hline Total & 407 & 100 \\
\hline
\end{tabular}

Source: Field Survey, 2014 
This study revealed that low level of technology, poor financial management, lack of logistics, deficient infrastructure, poor attitude of people towards waste management and the consequent disregard for rudimentary aesthetics are the major setbacks to sustainable solid waste management. Other constraints are improper management of solid wastes, ineffective enforcement of environmental laws and regulations, insufficient personnel, inadequate private participation in solid waste management, low status of waste management workers, lack of environmental education and awareness, as well as poor institutional frameworks. The study proclaims that better understanding, protection and improvement of the urban environment, as well as slum upgrading are pre-requisites to solid waste management.

\section{Recommendations}

Solid waste management encompasses the collection, storage, transportation, treatment and disposal of waste in such a way that it does not cause any harm to humans, plants, animals or the environment. It is a major strategy in the achievement of environmental sustainability. The governance of waste requires the collaborative efforts of individuals, government, non-governmental organizations, as well as international organizations. Individuals should cultivate the habit of waste reduction and pollution abatement in order to minimize the spread of diseases. Sustainable waste management should also enhance environmental sanitation, environmental friendly industrial activities, planned development, environmental hazards and risk assessment, as well as general environmental management. In order to maintain a safe, healthy and conducive, environment, there should be enforcement and implementation of laws against the indiscriminate disposal for waste. People should be made to comply to environmental laws and offenders should be punished.

The scientific community should assess the various methods of waste disposal and adopt the best practice with the minimum negative consequences upon the environment. To this end, the modern techniques of environmental monitoring and management like geographic information system, remote sensing and closed circuit television device should be used in the management of waste. Sanitary inspectors should be motivated in order for them to perform very well and the monthly environmental sanitation programme should be re-introduced in all states of the federation. In order to be able to reap the economic, aesthetic, social, educational, medicinal and other values of the environment, conservation of material resources and energy should be enhanced through re-use, recycling and reduction of waste. In this sense, more containers should be provided in strategic locations in order to enhance the house-to-house collection of wastes. Also, solid wastes should be collected and transported regularly. Above all, since women are more involved in domestic waste management, they should be given proper orientation and formal education in order to change their sanitation behaviour for better.

Moreover, there is urgent need to embark on meaningful community involvement and public participation in waste management. This should be reinforced by public enlightenment, environmental awareness and education on waste disposal and the repercussions of indiscriminate waste disposal. To this end, landlords should be made to provide latrines or toilet facilities, as well as solid waste bins in their houses so as to avoid littering and indiscriminate deifications in the environment. Likewise, workers dealing with solid waste management should be adequately remunerated because of the social stigma and the occupational hazards that are associated with their job. In addition, the government should control population growth, urbanization and urban development. Also, more institutional frameworks should be put in place for better management of waste. To this end, government agencies like Federal Environmental Protection Agency (FEPA) and National Emergency Management Agency (NEMA) should work in collaboration with non-governmental organizations like Nigerian Environmental Watch (NEW), Nigerian Environment and Study Team (NEST), Nigerian Environmental Society (NES), Foundation for Environmental Development and Education in Nigeria (FEDEN) and others in sustainable waste management. Above all, sustainable waste management requires the cooperation of the government with international agencies.

\section{Conclusion}

The components of solid wastes vary from country to country, place to place, and season to season. The process of its management includes generation, collection, sorting, storage, transportation, deposition, processing, recycling, disposal, as well as treatment. For the attainment of the time bound millennium development goals, it is pertinent to manage waste sustainably as it forms the fulcrum on which many of the goals rests. Sustainable management of waste involves the handling of wastes in socially acceptable, economically affordable and environmentally effective manner. This can significantly reduce sickness and diseases in the environment. It can also improve environmental quality and reduce the propensity of waste to cause other environmental hazards. Hence, there is need to raise environmental awareness on the need for sanitary disposal of waste so as to minimize its consequences. 


\section{References}

Abrokwah, K. (1988). Refuse Management Problems in Central Kumasi. Status Report on Population, Human Resources and Development Planning and Policy in Ghana. 1960-1987. Kumasi, Ashanti Press.

Ackerman, F. (1996) Why Do We Recycle? Market, Values, and Policy. Washington, D. C, Island Press.

Adedibu, A. A. (1986) Solid Waste Management and a New Environmental Edict: A Case Study from Ilorin, Kwara State, Nigeria. The Environmentalist 6 (1) 63-68.

Ademiluyi, I. L. and Solanke, M. O. (2004) Towards Effective Environmental Management for Sustainable Development in Nigeria. In Ibitoye, O. A. (ed.) Economic and Social Issues in Population, Environment and Sustainable Development in Nigeria. Ado-Ekiti, PETOA Educational Publishers. PP 157-164.

Ajadike, J. C. (2007) Urban Solid Wastes: Problems and Management in Nigeria. In Ocomata, G. E. K. and Phil-Eze, P. O. (eds.) Geographic Perspectives on Environmental Problems in Nigeria. Enugu, Jameo.

Akinbode, A. (2002) Introductory Environmental Resource Management. Ibadan, Daybis Limited.

Akinro, A. O.; Ikumawoyi, O. B.; Olotu, Y. and Ologunagba, M. M. (2012): Environmental Impacts of Polyethytene Generation and Disposal in Akure City, Nigeria. Global Journal of Science Frontier Research of Agriculture and Biology 12 (13) 1-7.

Ayeni, M. A. O. (1978) Pattern Process and Problems of Urban Development. In Oguntoyinbo, J. S., Filani, M. O. and Areola, O. O. (eds.) A Geography of Nigeria Development. Ibadan, Heineman Educational Books (Nig) Ltd.

Environmental Protection Agency (1973) Solid Waste Management Glossary. Washington, Environmental Protection Agency.

Eseigbe, T. O., Omofonmwan, S. I.; and Kadiri, M. A. (2007) Solid Waste Generation and Management in Benin Metropolis. Confluence Journal of Environmental Studies 2 (2) 34-44.

Fakere, A. A. Fadairo, G. and Oriye, O. (2012) Domestic Waste Management and Urban Residential Environment: Focus on Akure, Nigeria. International Journal of Engineering and Technology 2 (5) 878-886.

Franca, A. (2002) Strategies for Participatory Communal Action for Environmental Protection. Journal of Conservation 1 (1) 24-32.

Garg, S. K. and Gang, R. (2013) Environmental Studies and Green Technologies, Delhi, Khanna Publishers.

Gourlay, K. A. (1992) World of Waste: Dilemmas of Industrial Development. London, Zed Book Limited.

Iftekhar, E. (2004) Household Waste Management. Footsteps 59 (1) 10-11.

Kadafa, A. A.; Latifah, A. M.; Abdullah, H. S. and Sulaiman; W. N. A. (2013) Current Status of Municipal Solid Waste Management Practise in FCT Abuja. Research Journal of Environment and Earth Sciences 5 (6) 295-304.

Kayode, A. M. and Omale, F. K. (2011) Some Socio-Economic Factors Affecting Solid Wastes Generation and Disposal in Ibadan Metropolis, Nigeria. Journal of Environmental Issues and Agriculture in Developing Countries. 3 (1) 55-64.

Kharbanda, O. O. and Stallworthy, E. A. (1992) Waste Management. New York, Auburn House.

Malombe, J. M. (1994) Sanitation and Solid Waste Disposal in Milindi, Kenya, 19th Water, Sanitation, Environment and Development Conference Preprint, Ghana.

Mangizvo, V. R. (2010) An Overview of the Management Practices at Solid Waste Disposal Sites in African Cities and Towns, Journal of Sustainable Development in Africa. 12 (7) 233-239.

Musa, S. D. (2006) Solid Waste Management in Ankpa. Confluence Journal of Environmental Studies 1 (1) 35-44.

NERC (2006) The Environment: Identifying and Tackling Problems. Swindon, NERC

Nigerian Institute of Safety Professional (2003) Contractor Employee HSE Training Manual, Level 3. Port Harcourt, ECNCEL Publishers.

Ojeifo, O. M. and Uwadiae, B. T. (2003) Waste Disposal Problems in Emerging Urban Centres: The Case of Ekpoma and Irrua in Edo State. International Journal of Environment and Development 6 (2) 65-72.

Oluwande, P. A. (1983) A Guide to Tropical Environmental Health and Engineering. Ibadan, Nigerian Institute of Social and Economic Research.

Omuta, G. E. D. (1988). Urban Solid Waste Generation and Management Towards an Environmental Sanitation Policy. In Sada, P. O. and Odemerho F. O. (eds). Environmental Issues and Management in Nigerian Development. Ibadan, Evans Brothers Nigerian Publishing Ltd.

Osinowo, F. A. (2001) Towards Effective Waste Management in Nigeria. Lagos, Nigerian Conservation Foundation.

Rao, C. S. (2006) Environmental Pollution Control Engineering. New Delhi, New Age International Limited.

Stirrup, F. C. (1965) Public Cleansing and Refuse Disposal. Oxford, Percamon Press.

Zhiyong, H.; Dan, L.; Yunhu, L.; Jing, W. and Shulan, L. (2015) Characteristics and Management of Domestic Waste in the Rural Area of Southwest China. Waste Management Resources 3 (1) 39-47. 